Dr Radovan Grandić ${ }^{6}$,

UDC: $378: 316.663$

Filozofski fakultet u Novom Sadu,

$378: 316.7$

Univerzitet u Novom Sadu, Novi Sad, Srbija

MA Maja Bosanac ${ }^{7}$,

DOI: $10.19090 /$ ps.2018.2.143-157
Primljen: 3.12 .2018$.

Filozofski fakultet u Novom Sadu,

Univerzitet u Novom Sadu, Novi Sad, Srbija

Primljen: 3.12 .2018$.

PREGLEDNI NAUČNI RAD

\title{
PROMENE U AKADEMSKOJ PROFESIJI I DRUŠTVENI ANGAŽMAN UNIVERZITETSKIH NASTAVNIKA ${ }^{8}$
}

\section{Rezime}

Otvorenost univerziteta prema zajednici postala je predmet brojnih kritika, ali isto tako $i$ novih mogućnosti. Bez obzira na pristup od kojeg se polazi, otvorenost univerziteta prema zajednici nezaobilazan je deo funkcionisanja današnjih univerziteta. Pored nastave $i$ istraživanja, kao osnovnih akademskih delatnosti, sve češće se govori $i$ o trećoj misiji univerziteta koja se u najširem smislu može definisati kao interakcija univerziteta i zajednice, što velikim delom utiče i na obrazovne politike, kako na lokalnom, isto tako i globalnom nivou. Kao cilj rada postavlja se sagledavanje uloge koju univerzitetski nastavnici imaju kada je reč o društvenom angažmanu što predstavljamo kroz prikaz istraživanja iz prakse u Republici Srbiji realizovanog od strane Centra za obrazovne politike. Uz to, u analitičkom delu rada pažnja se usmerava i na reinterpretaciju akademske profesije, kao i predstavljanje različitih scenarija o budućnosti akademske profesije. Imajući u vidu da je ovo područje istraživanja nedovoljno proučeno u Republici Srbiji, u zaključku postavljamo i pitanja koja bi mogla da budu od značaja kako za pedagošku teoriju, isto tako i za pedagošku praksu.

Ključne reči: univerzitet, zajednica, uloga nastavnika

\footnotetext{
6 grandic@neobee.net

7 bosanacmaja4@gmail.com

${ }^{8}$ Rad je nastao u okviru projekta: Pedagoški pluralizam kao osnova strategije obrazovanja (179036) koji finansira

Ministarstvo prosvete, nauke i tehnološkog razvoja.
} 


\section{Uvod}

Reforma obrazovanja, u ovom slučaju misli se na reformu visokoškolskog obrazovanja, velikim delom podrazumeva promene, koje su sprovedene kao politički proces na najvišem nivou (top-down), a odnose se pre svega na bolonjski proces, pri čemu nije ostvaren dijalog sa širom akademskom zajednicom (prema: Rončević i Rafajac, 2010). Polazeći od sličnih osnova i kritika, Gojkov, Stojanović i Radić (2015) proučavaju kvalitet visokoškolskog obrazovanja iz ugla organizacionih koncepta transformacije visokog obrazovanja. U ovom radu detaljnije se bavimo analizom promena u akademskoj profesiji, pre svega aspektu koji podrazumeva društvenu angažovanost univerzitetskih nastavnika $\mathrm{u}$ poslovima van redovnih nastavnih i istraživačkih poslova, kako u akademskoj zajednici tako i van nje. S obzirom da je ovo nedovoljno proučeno područje u akademskoj zajednici $u$ Republici Srbiji, prikazom istraživanja koje je realizovano u okviru Centra za obrazovne politike, pažnju usmeravamo na analitički pristup različitim modelima akademske profesije jer one u budućnosti velikim delom mogu da budu uslovljene upravo društvenim faktorima Iz tog razloga, značajnim smatramo proučavanje odnosa između univerziteta $\mathrm{i}$ okruženja, te $u$ tom cilju predstavljamo nekoliko mogućih scenarija za buduće univerzitete, zajedno sa ulogom koju univerzitetski nastavnici imaju u ovom procesu. Za naš analitički pristup od najvećeg značaja su predviđanja o reinterpretaciji akademske profesije. Prema jednom od scenarija, naglasak se stavlja upravo na socijalne ili životne veštine koje će u budućnosti još više dobiti na značaju i upravo u tom kontekstu smatramo relevantnim proučavanje odnosa univerziteta i njegovog okruženja, ali pažnju usmeravamo i na potencijalne opasnosti. Ceo rad usmeren je na proučavanje implikacija pluralističke scene postmoderne pedagogije i njenog uticaja na visoko obrazovanje.

\section{Univerzitet i okruženje}

Razvoj obrazovanja, u svom najširem značenju, u današnje vreme nije toliko podstican svojom unutrašnjom dinamikom, kao što je to bio slučaj u prošlosti, već je postao daleko osetljiviji prema spoljašnjim pritiscima (Milutinović, 2008). U tom smislu, konstantni zahtevi za unapređenjem univerziteta, koji dolaze iz različitih sektora društva, čine aktuelnim istraživanje odnosa univerziteta i njegovog spoljašnjeg okruženja.

Promišljanja na temu odnosa univerziteta i njegovog okruženja mogu da se dovedu u vezu sa proučavanjem treće misije univerzieteta. U priručniku Strategic management of University research activities, kojeg je 2006. godine izdao Observatory of the European University i započeo tako prvi međunarodni projekat utvrđivanja aktivnosti treće misije i 
razvoja pokazalaca uspešnosti univerziteta u njihovom realizovanju ističe kako: „, treća misija univerziteta podrazumeva saradnju univerziteta s neakademskom zajednicom: ekonomijom, javnim sektorom i širom društvenom zajednicom. Treća misija je višedimenzionalan koncept koji uključuje nekoliko različitih aktivnosti poput komercijalizacije akademskog znanja razvojem javno privatnih partnerskih istraživačkih projekata, razvoja patenata i licenciranih proizvoda te stvaranja spin off preduzetničkih kompanija u vlasništvu univerziteta s jedne strane, i učestvovanja u javnim raspravama i procesu stvaranja javnih politika, kao i angažovanja u društveno-kulturnom životu zajednice, s druge strane. Iako povezana $s$ nastavom kao prvom, a posebno istraživanjem ako drugom misijom univerziteta, treća misija univerziteta posebna je misija, prožeta kroz ekonomsku i društvenu dimenziju svojih aktivnosti, koje govore o načinima i mehanizmima integracije univerziteta u zajednicu te omogućavaju analizu i raspravu o doprinosu univerziteta razvoju ekonomije i društva“ (Schoel, 2006 prema: Ćulum i Ledić, 2011: 21).

Raspravljanje o univerzitetskim misijama rezultiralo je pluralizmom pristupa i stavova o ulozi univerziteta u društvu. Tako na primer, za razliku od Njumana (Newman, 1873), koji se zalagao za misiju nastave i poučavanja slobodnih veština i iskazivao neslaganje sa promenljivom ulogom univerziteta, Fleksner (Flexner, 1994) je zagovarao istraživačku misiju univerziteta, dok je ulogu nastave i delovanja u zajednici smatrao manje važnima. Proučavanje krize identiteta univerziteta iz perspektive filozofije zasniva se na drugačijim osnovama, pri čemu se razlozi krize ne pronalaze samo u spoljašnjoj prirodi, odnosno u vezanosti za društveno-ekonomsku modernizaciju, već se ističe da su problemi i suštinske prirode, tj. da su vezani za unutrašnje teškoće same ideje (Dimić, 2013). U trenutku najvećeg zanemarivanja izvornih vrednosti ideje univerziteta, kada od tri Humboltova principa: jedinstva nauke, jedinstva nastave $\mathrm{i}$ istraživanja, akademske slobode profesora i studenata nije ostalo ništa, ili gotovo ništa dijagnoza je, naime, glasila da je univerzitet ostao bez svoje ideje (Dimić, 2013).

U ovom radu polazi se od stava da je za pedagoški istraživački rad najsveobuhvatnija podela tumačenja treće misije univerziteta koju predstavljaju Bojana Ćulum i Jasminka Ledić (2011:25), a koja podrazumeva sledeće: (1) treća misija kao doprinos univerziteta ekonomskom razvoju (u literaturi se naziva ekonomskom, tehnološkom ili komercijalnom trećom misijom), (2) treća misija kao doprinos univerziteta razvoju civilnog društva i demokratije (dominantan termin je civilna misija), (3) treća misija kao integrativni koncept međusektorske saradnje u doprinosu razvoja lokalne zajednice, (4) treća misija kao osnov 
akademske profesije i odgovornost univerzitetskih nastavnika u razvoju univerziteta i lokalne zajednice.

Pored pluralizam pristupa kao odgovor na pitanje šta uopšte podrazumeva treća misija univerziteta, slične nesuglasice mogu da se uoče i kada je reč o institucionalizaciji treće misije univerziteta. Mugabi (Mugabi, 2014) naglašava kako se neki od izazova za institucionalizaciju treće misije univerziteta nalaze u činjenici da okviri za produkciju znanja često posmatraju univerzitete kao jedine kreatore, konzervatore i prenosnike znanja i vrednosti i ignorišu relevantnost spoljašnjih zajednica u produkciji znanja, a u prilog ovakvom shvatanju ide činjenica da su univerziteti posebni upravo iz razloga što su odvojeni od trenutka. Svoju analizu o trećoj misiji univerziteta navedeni autor zasniva na osam aspekata koje smatra krucijalnim za institucionalizaciju treće misije univerziteta: univerzitetska misija, zapošljavanje i prakse promocije, organizaciona struktura, uključenost i posvećenost fakulteta, studentska uključenost, uključenost zajednice, publikacije i, konačno, komunikacija kampusa i liderstvo i podrška.

Posmatrano u celini, koncept treće misije univerziteta obuhvata mnoge od zahteva koji se stavljaju pred univerzitete kako bi preuzeli vidljivu ulogu u podsticanju upotrebe znanja za društveni, kulturni i ekonomski razvoj. Pored toga, istraživanja ukazuju i na svetski trend individualističkog načina rada i zanemarivanja (saradničkih) aktivnosti koje doprinose obrazovanju društveno odgovornih i aktivnih građana među mladim saradnicima i nastavnicima (Macfarlane 2007; Karlsson, 2007: prema: Ćulum i Ledić, 2011).

Goranson i sar. (Göransson, Maharajh \& Schmoch, 2009) uočavaju, takođe, da postoje značajne varijacije između zemalja i različitih konteksta u pogledu toga kakve funkcije treba da se uključe u treću misiju univerziteta. One sežu od fokusa na transferu tehnologija od strane univerziteta prema preduzećima (u Nemačkoj) do šireg latinoameričkog koncepta proširenja uloge univerziteta da služe potrebama zajednice. Jedna od kritika upućena visokom obrazovanju odnosi se, naime, na to da institucije treba više da doprinose svojim zajednicama (Lombardi, 2001). Pojedini autori (Lucas, 1994; Rice, 1996) visoku profesionalizaciju i odanost disciplini dovode u vezu sa porastom broja univerziteta, alijenacijom u uske okvire discipline, kao i intenziviranjem istraživanja zbog finansijske koristi i karijere, a ne dobrobiti zajednice i društva.

Dakle, otvorenost univerziteta prema zajednici može da bude posmatrana kao vid novih mogućnosti kroz saradnju sa javnim i privatnim institucijama, ali isto tako mora da se postavi pitanje adekvatnosti prilikom izbora partnera. 
U nastavku predstavljamo jedan od mogućih budućih scenarija za univerzitete, koji treba da budu posmatrani, kako kroz svoje prednosti, isto tako i mane (Vincent-Lancrin, 2004): (1) Tradicija - pri čemu je isključiva usmerenost na nastavu i istraživanje, bez značajne zavisnosti ili uključenosti privatnog sektora. Vlast nastavlja da igra ključnu ulogu $u$ finansiranju, regulisanju i upravljanju univerzitetom. Celoživotno i e-učenje u ovom scenariju većinom su razvijeni van univerzitetske sfere. Ovaj scenario je selektivan, studenti su većinom mladi, univerzitet je većinom javno finansiran. Nastava i istraživanje prevladavaju, sa snažnijim istraživanjem, pri čemu je nacionalni fokus od značaja. (Vincent-Lancrin, 2004). (2) Preduzetnički univerzitet - ključna razlika od prethodnog scenarija jeste da univerziteti (javni ili privatni) mogu da odgovore sa većom autonomijom različitim izvorima finansiranja. Više je mešovitog javno - privatnog modela finansiranja, izvori univerziteta dolaze iz različitih vrsta izvora. Zajedno sa intelektualnom svojinom, prava koja osigurava istraživanje je veoma važna i unosna aktivnost. Ipak, ovaj scenario univerziteta iako podrazumeva tržišno usmeren pristup, ne gube se osnovne akademske vrednosti. S obzirom da se prestiž i prihodi dobijaju istraživanjem, nastavna strana ostaje zapostavljena. Celoživotno učenje se realizuje unutar univerziteta, ali samo u nastavnim institucijama sa nižim statusom. Tri misije univerziteta su balansirane, postoji veća diferencijacija zahvaljujući: (a) povećanoj autonomiji, (b) povećanoj odgovornosti. Komercijalni pristupi e-učenju su važni, kao i veze sa lokalnom ekonomijom koje su jake (Vincent-Lancrin, 2004). (3) Slobodno tržište - tržište je osnovni pokretač ovog scenarija sa privatnim terijarnim sektorom koji je regulisan od strane privatnih kompanija, kao i osiguravanja kvaliteta i akreditacija koja se odnosi na finansiranje kroz mehanizme tržišta. Sile tržišta daju uspon institucijama koje postaju specijalizovane po funkciji: nastava, istraživanje; polju-biznis, humanističke; publici-mladi studenti, povremeni studenti, obrazovanje na daljinu, odrasli, celoživotno obrazovanje. Hijerarhija između različitih institucija postaje jaka, globalna super elita i više polarizovana statusom fakulteta. Širenjem studentskog izbora veće je takmičenje za studente i školarine predstavljaju sve važniji deo generalnog prihoda. Tehnologija se mnogo koristi u nastavnim metodama, tržišna usmerenost na internacionalnom nivou postaje značajna. Istraživanje postaje više vođeno potrebama, specijalizovano i osigurava značajne povratke kroz prava intelektualnog vlasništva (Vincent-Lancrin, 2004). (4) Celoživotno učenje i otvoreno obrazovanje-univerziteti su označeni univerzalnim pristupom za sve godine. Cvetanje ekonomije znanja i visokog obrazovanja postaje izvor za povratak, profesionalni razvoj finansiran od strane kompanija, pojedinaca koji traže usavršavanje prepoznatih veština. Univerziteti postaju više orijentisani prema onima koji uče i potrebama, više nastavno 
orijentisani sa kratkim kursevima. Većina istraživanja je realizovana van sistema visokog obrazovanja, sa najboljim istraživačima koji idu u privatne kompanije, specijalizovane institute ili par preostalih elitnih univerziteta. Korporacije i korporativni univerziteti imaju velik uticaj. Integracija sa primenjenom stranom učenja može da ide tako daleko da celokupno univerzitetsko obrazovanje sledi profesionalni školski model. Odgovornost silama tržišta je visoka u ovom scenariju i postoji značajno biznis ulaganje u e-učenje (VincentLancrin, 2004). (5) Post sekundarne studije postaju vođene: (a) zahtevom/potražnjom, (b) tržištem. Dve glavne inovacije su: (a) oni koji uče definišu svoje studije i kurseve kroz sve dostupne kurseve iz obrazovne mreže, (b) partnerstvo institucija visokog obrazovanja se povećava, uključujući sa industrijom. E-učenje se mnogo razvija u ovom scenariju. Sadržaj treninga postaje sve više standardizovan i zasnovan na tehnologiji i medijima. Provizija od tržišta, celoživotno učenje postaje veliko, većina istraživanja se odvija van sistema visokog obrazovanja i fakultet u većini slučajeva postaje manje kvalifikovan nego danas. Postoji snažna polarizacija u statusu. Programi i kursevi znače više nego institucije (Vincent-Lancrin, 2004). (6) Različitost prepoznatog učenja-u ovom scenariju, sektor formalnog terijarnog obrazovanja nestaje. Ljudi uče kroz život, na poslu, u kući, zbog personalnih i profesionalnih motiva, sve više njih samostalno i kroz deljenje njihove ekspertize sa drugim ljudima zainteresovanim za isto polje. Profesionalno obrazovanje zahteva direktan odnos sa praksom, šegrtovanjem ili zahvaljujući novim sofisticiranim on-line uređajima. Tehnologija omogućava difuziju informacija i znanja. Ljudi uče kao danas ili više, ali na drugačiji način, učenje poprima model „otvorenog kursa“ većinom besplatnog i nekomercijalnog uključujući mnoga partnerstva između pojedinaca i institucija svih vrsta. Globalno umrežavanje je važno i ide van institucija. Znanje i iskustvo su zahtevani u svim životnim situacijama i priznati kroz formalno merenje, ali sa datom svakodnevnošću, znanje je manje određeno za karijeru ili stratifikaciju društva (Vincent-Lancrin, 2004).

Degradacija univerzitetskog obrazovanja, pre svega u poslednjem scenariju mogla bi da se analizira na više nivoa, ali za potrebe našeg rada od najvećeg značaja je odgovor na pitanje: Šta se dešava sa humanističkom stranom obrazovanja? Ko je podstiče, i na koje načine? Da li ona iščezava usled isključive usmerenosti na upotrebnu vrednost znanja?

\section{Promene u akademskoj profesiji}

Gore pomenute promene mogu da rezultiraju i implikacijama za akademsku profesiju, te kada je reč o budućnosti akademske profesije Rončević i Rafajac (2010) navode kako postoji nekoliko scenarija koji se zasnivaju na međunarodnim raspravama i rezultatima 
istraživanja: (1) Rast uloge nauke u društvu dovešće do toga da će akademska profesija postati ključna profesija (Clark, 1997), (2) Akademska profesija na tragu je da izgubi ključnu poziciju unutar visokog obrazovanja i daljeg razvoja društva. Deprofesionalizacija, birokratizacija i marginalizacija su reči koje se sve češće koriste, predviđa se propadanje tradicionalnih oblika, a akademska profesija se percipira kao institucionalni resurs koji pruža više ili manje učinkovitu uslugu (Clark, 1997), (3) U postmodernom društvu akademska će profesija biti potpuno reinterpretirana, pri čemu se ističe kako će naglasak biti na socijalnim ili čak životnim veštinama i nastavnici će biti u ulozi interpretatora istine kao relativnog koncepta. Istraživanje će biti organizovano horizontalno, radije nego vertikalno, pluralističko, transdisciplinarno, brzo će se menjati i postaće socijalno odgovorna aktivnost (Gibbons et al, 1994), (4) Univerziteti će postati marginalne institucije, a akademska će profesija, opirući se promenama, postati "antikna" i izgubiti svoju centralnu poziciju u kulturnoj reprodukciji i kreiranju novih znanja (Scott, 1997 prema: Rončević i Rafajac, 2010:12).

U celini posmatrano, iz prethodno navedenih scenarija, moguće je zaključiti kako će promene u akademskoj profesiji u budućnosti velikim delom biti uslovljene upravo društvenim promenama. Upravo iz tog razloga relevantnim smatramo proučavanje uticaja savremenih društvenih promena na viskoškolsko obrazovanje, kao i na promene u akademskoj profesiji.

Pitanje koje možemo da postavimo jeste, da li će univerziteti kao mesta na kojima se prenose stara i stvaraju nova znanja postati marginalne institucije upravo u periodu u kojem se akcentuje sintagma društva znanja?

Pomeranje od fundamentalnih ka primenjenim istraživanjima povećava broj kompetentnih aktera koji učestvuju u vanuniverzitetskoj proizvodnji znanja, što znači da univerzitet gubi privilegovan položaj, posebno u istraživačkoj komponenti (Marcelić, 2015). Rezultati Turkovog istraživanja (Turk, 2016) između ostalih kao (nove) kompetencije akademske profesije ukazuju na: kompetencije za saradnju sa ekonomijom i širom zajednicom, kompetencije za celoživotno učenje, kompetencije upravljanja ljudskim potencijalima, te popularizacijske kompetencije.

\section{Društveni angažman akademskog osoblja u Srbiji}

U okviru međunarodnog istraživanja, jednog od najpoznatijih koje se bavilo temom akademske profesije, Promene u akademskoj profesiji (The Changing academic profession) $\mathrm{u}$ analizi se zaključuje da postoje tri ključna pitanja koja će u budućnosti da utiču na vitalnost visokog obrazovanja u svetu (prema: Turk, 2016). Za naš analitički pristup ovoj temi od 
značaja je proučavanje trećeg pitanja koje podrazumeva odnos nastave, istraživanja i delovanja u zajednici.

Centar za obrazovne politike 2012. godine izvršio je istraživanje o društvenoj odgovornosti univerziteta čiji konceptualni okvir istraživanja su činila četiri međusobno različita, ali međusobno povezana segmenta akademskog života: (1) društveni angažman pripadnika akademske zajednice, (2) profesionalna karijera i uslovi rada $\mathrm{u}$ akademskoj profesiji-radni staž, dodatne aktivnosti, primanja, promena posla, uslovi rada, zadovoljstvo poslom, opterećenje, (3) naučno-istraživački rad-istraživački rad vs nastava; saradnja, publikovanje; finansiranje, (4) vrste upravljanja i administracija - uticaj, ocenjivanje (dostupno na: http://www.finhed.org/media/files/Dru\%C5\%A1tveni\%20anga\%C5\%Beman \%20 akademskog\%20osoblja\%20u\%20Srbiji\%20-\%20Ivana\%20Zivadinovic.pdf).

Detaljan prikaz svih rezultata prelazi granice ovog rada, te će stoga on biti ograničen samo na dodirne tačke s problematikom našeg rada. Pitanju aktivizma pristupljeno je iz ugla društvenog i stručnog aktivizma. Ukupno je istraživano 16 aktivnosti od čega su 6 aktivnosti stručnog aktivizma i 10 aktivnosti društvenog aktivizma. U cilju prikazivanja koliko značajnim se smatraju određene aktivnosti (Tabela 1) prikazujemo procente za odgovore koji su vrednovani kao veoma važni, dok, s druge strane, zbog slabog sprovođenja aktivizma prikazujemo procentualne rezultate onih koji nikada nisu učestvovali.

Tabela 1. Vrednovanje značaja aktivnosti stručnog aktivizma kao i stepen stručnog aktivizma u navedenim aktivnostima

\begin{tabular}{|c|c|c|}
\hline & $\begin{array}{l}\text { ocena } \\
\text { važnosti: } \\
\text { veoma važno }\end{array}$ & $\begin{array}{l}\text { stepen } \\
\text { aktivizma: } \\
\text { nikada }\end{array}$ \\
\hline $\begin{array}{l}\text { Učešće u javnim raspravama i } \text { stručnim } \\
\text { konsultacijama o predlozima zakona i regulatornih } \\
\text { akata koji su u domenu Vaše struke }\end{array}$ & $71.8 \%$ & $53.1 \%$ \\
\hline $\begin{array}{l}\text { Učešće u radnim grupama za izradu zakona i } \\
\text { regulatornih akata. }\end{array}$ & $67.4 \%$ & $65.3 \%$ \\
\hline $\begin{array}{l}\text { Učešće u radu komisija na fakultetu na kome radite } \\
\text { (ne računajući komisije za odbranu radova) }\end{array}$ & $63.1 \%$ & $30.4 \%$ \\
\hline Učešće u radu radnih grupa pri Univerzitetu & $61 \%$ & $43.3 \%$ \\
\hline $\begin{array}{l}\text { Gostovanje na radio i/ili TV emisijama sa stručnom } \\
\text { tematikom }\end{array}$ & $58.8 \%$ & $41.1 \%$ \\
\hline Pisanje stručnih članaka za novine. & $49.8 \%$ & $44.3 \%$ \\
\hline
\end{tabular}

Prilagođeno: Univerzitet i treća misija u regionu i šire: Društveni angažman akademskog osoblja u Srbiji (2013)

Kao što može da se zaključi iz odgovora, bez obzira na činjenicu da većinu aktivnosti veliki procenat ispitanika smatra veoma značajnim, istovremeno, iznenađujuće je velik 
procenat onih koji nikada nisu učestvovali u navedenim aktivnostima. Kada je reč o društvenom aktivizmu (Tabela 2), odgovori su mnogo drugačiji.

Tabela 2. Vrednovanje značaja aktivnosti društvenog aktivizma, kao i stepen društvenog aktivizma

\begin{tabular}{|c|c|c|}
\hline & $\begin{array}{l}\text { ocena } \\
\text { važnosti: } \\
\text { veoma važno }\end{array}$ & $\begin{array}{l}\text { stepen } \\
\text { aktivizma: } \\
\text { nikada }\end{array}$ \\
\hline $\begin{array}{l}\text { Učešće na tribinama, javnim predavanjima, } \\
\text { organizovanim javnim skupovima. }\end{array}$ & $51.2 \%$ & $20.7 \%$ \\
\hline $\begin{array}{l}\text { Praćenje dešavanja u politici uopšte }-\mathrm{TV} \text {, radio, } \\
\text { novine }\end{array}$ & $37.4 \%$ & $19.5 \%$ \\
\hline Saradnja sa organizacijama iz civilnog sektora. & $34.7 \%$ & $42.4 \%$ \\
\hline 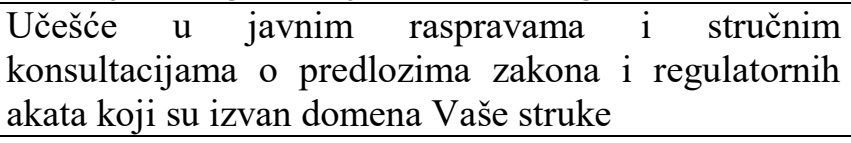 & $19.7 \%$ & $81.8 \%$ \\
\hline Potpisivanje peticija o različitim pitanjima. & $19.1 \%$ & $27.8 \%$ \\
\hline $\begin{array}{llllll}\begin{array}{l}\text { Gostovanje na radio } \\
\text { aktivističkom tematikom. }\end{array} & & & & \text { TV emisijama } & \text { sa } \\
\end{array}$ & $16.8 \%$ & $77.3 \%$ \\
\hline $\begin{array}{l}\text { Učešće na demonstracijama, protestima, mitinzima i } \\
\text { sl. }\end{array}$ & $15.2 \%$ & $43.5 \%$ \\
\hline Učešće u štrajkovima. & $13.4 \%$ & $68.5 \%$ \\
\hline Pisanje članaka na blogovima. & $11.9 \%$ & $80 \%$ \\
\hline Pisanje aktivističkih članaka za novine. & $10.2 \%$ & $85.8 \%$ \\
\hline
\end{tabular}

Prilagođeno: Univerzitet i treća misija u regionu i šire: Društveni angažman akademskog osoblja u Srbiji (2013)

Kao što je moguće uočiti, postoje velike razlike u značaju koji ispitanici pridaju različitim aktivnostima društvenog aktivizma, kao i stepenu njihovog učešća u istima. Zanimljivo je da, iako neke od aktivnosti ispitanici ne smatraju veoma važnima, stepen aktivizma je veoma visok što može da se poveže sa odgovorima koji se procentualno najviše vezuju za vrednovanje svake od aktivnosti kao delimično važne (u rasponu od 30-48\%).

Rezultati stručnog aktivizma na institucionalnom nivou (Tabela 3), nažalost, pokazuju veliki procenat neupućenosti ispitanika u delovanje matične institucije, stoga kao jedan od razloga za potrebom aktuelizovanja bavljenjem ovom temom, između ostalog ističemo i razloge informativne prirode. Čak i ako određen broj nastavnika smatra da njihova uloga nije realizovanje saradnje sa širom zajednicom, prema rezultatima ovog istraživanja velik broj nastavnika nije ni upućen $u$ mogućnosti saradnje sa različitim telima i institucijama $u$ okruženju. Smatrajući da je uloga univerzitetskih nastavnika najznačajnija u procesu razvoja treće misije univerziteta (posebno dela koji se odnos na civilnu misiju), ovom pitanju trebalo bi posvetiti veću pažnju u budućnosti. 
Tabela 3. Procenat neupućenosti ispitanika na delanje matične institucije

\begin{tabular}{|c|c|}
\hline Odnos prema stručnom aktivizmu na stručnom nivou (u \%) & $\begin{array}{l}\text { Nisam } \\
\text { upoznat/a }\end{array}$ \\
\hline $\begin{array}{l}\text { Moja matična ustanova javno oglašava svoj stav o aktuelnim } \\
\text { dešavanjima u društvu kada se ona dotiču njene oblasti rada (struke). }\end{array}$ & 31.5 \\
\hline $\begin{array}{l}\text { Moja matična ustanova ušestvuje u interdisciplinarnim tumačenjima } \\
\text { aktuelnih globalnih fenomena }\end{array}$ & 37.5 \\
\hline $\begin{array}{l}\text { Moja matična ustanova organizuje stručne rasprave i javne debate od } \\
\text { šireg značaja za razvoj društva na teme koje su u njenom delokrugu }\end{array}$ & 23 \\
\hline $\begin{array}{l}\text { Moja matična ustanova (fakultet/institut) sarađuje sa strukovnim } \\
\text { udruženjima. }\end{array}$ & 21 \\
\hline $\begin{array}{l}\text { Studenti na mojoj matičnoj ustanovi samostalno organizuju razgovore i } \\
\text { debate na teme od značaja za razvoj društva }\end{array}$ & 40.4 \\
\hline $\begin{array}{l}\text { Studenti u mojoj matičnoj ustanovi pokreću inicijative ili organizuju } \\
\text { projekte koji tretiraju pojedine opšte probleme aktuelne za društvo u } \\
\text { Srbiji }\end{array}$ & 34.6 \\
\hline $\begin{array}{l}\text { Moja matična ustanova (fakultet/institut) sarađuje sa političkim } \\
\text { partijama/organizacijama }\end{array}$ & 53 \\
\hline $\begin{array}{l}\text { Moja matična ustanova (fakultet/institut) sarađuje sa humanitarnim } \\
\text { organizacijama }\end{array}$ & 39.1 \\
\hline $\begin{array}{l}\text { Moja matična ustanova (fakultet/institut) } \\
\text { organizacijama građanskoje }\end{array}$ & 30.5 \\
\hline $\begin{array}{l}\text { Moja matična ustanova (fakultet/institut) sarađuje sa kulturnim } \\
\text { institucijama }\end{array}$ & 29.5 \\
\hline Moja matična ustanova (fakultet/institut) sarađuje sa medijima & 14.3 \\
\hline
\end{tabular}

Prilagođeno: Univerzitet i treća misija u regionu i šire: Društveni angažman akademskog osoblja u Srbiji (2013)

\section{Uloga univerzitetskih nastavnika u odnosu sa zajednicom}

Značaj proučavanja uloge univerzitetskih nastavnika dovodimo $u$ vezu sa realizovanjem osnovnih funkcija univerziteta. Kao osnovne funkcije univerziteta Dušan Savićević (2009, prema Gvozdenović, 2010) razlikuje profesionalnu, socijalnu, naučnu i kulturnu funkciju. Za naš analitički rad od najvećeg značaja je proučavanje socijalne funkcije visokog obrazovanja, odnos autonomije univerziteta sa jedne strane, ali i pitanje fleksibilnosti i mogućnosti univerziteta da odgovori potrebama i zahtevima društva, na drugoj strani (Gvozdenović, 2010:56).

Makfarlanov model (Macfarlane 2007, prema: Ćulum i Ledić: 2011) komponenti akademske profesije (Tabela 4) prepoznat je, i često citiran kao značajan doprinos akademskoj raspravi o dimenzijama treće misije univerziteta, pre svega društvenoj odgovornosti univerzitetskih nastavnika. 
Tabela 4. Komponente akademske profesije

\begin{tabular}{|c|c|}
\hline Komponente akademske profesije & Implikacije za univerzitetske nastavnike \\
\hline Politička pismenost & $\begin{array}{l}\text { Razumevanje procesa upravljanja i donošenja } \\
\text { odluka na svim nivoima univerziteta: praćenje } \\
\text { novih politika i učestvovanje u raspravama: } \\
\text { prema prilici, aktivno učestvovanje u vršenju } \\
\text { upravljačkih funkcija }\end{array}$ \\
\hline Društvena i moralna odgovornost & $\begin{array}{l}\text { Razumevanje i prihvatanje odgovornosti za } \\
\text { razvoj studenata, kolega, univerziteta, } \\
\text { akademskih i stručnih tela, interesnih grupa u } \\
\text { lokalnoj zajednici i društvu u širem smislu }\end{array}$ \\
\hline $\begin{array}{lrl}\text { Zalaganje } \quad \text { u } & \text { zajednici } & \text { (akademskoj } \\
\text { neakademskoj) }\end{array}$ & $\begin{array}{l}\text { Znanja i veštine za mentorisanje studenata, } \\
\text { podrška kolegama na univerzitetu i struci, } \\
\text { primenjena istraživanja zasnovana na potrebama } \\
\text { zajednice i razvoj novih znanja odnosno rešenja } \\
\text { za uočene potrebe i probleme: komunikacija i } \\
\text { interakcija s javnosti }\end{array}$ \\
\hline
\end{tabular}

Izvor: Ćulum i Ledić, (2011)

Ovako postavljene komponente akademskog građanina podrazumevaju da univerzitetski nastavnik poseduje odgovarajuća znanja (politička pismenost), ključne vrednosti (povezane sa društvenom i moralnom odgovornošću) i veštine zalaganja u akademskoj zajednici i šire. Akademski bi građanin, sudeći po Makfarlanu (Macfarlane, 2007 prema: Ćulum i Ledić, 2011:47), trebao da polazi od toga da je visokoškolsko obrazovanje mnogo više od pružanja i usvajanja korisnih znanja i veština za tržište rada, da je istraživanje alat za rešavanje problema lokalne zajednice i društva, a ne samo za objavljivanje, individualnu promociju i napredovanje (prema: Ćulum i Ledić, 2011:47).

Makfarlan, (Macfarlane, 2007 prema: Ćulum i Ledić, 2011:47) ističe kako su univerzitetski nastavnici u svom svakodnevnom radu u konstantnoj interakciji sa pet različitih zajednica, a čiji se interesi, međusovno razlikuju i prožimaju: studenti, kolege, matična institucija, naučna disciplina, struka i javnost. Razlike u značaju mogu da se mere u odnosu na niz međusobno povezanih činilaca koji se vrednuju u akademskoj zajednici: u kojoj je meri aktivnost prepoznata kao akademska, da li je povezana s akademskom ili neakademskom zajednicom, koliko je vidljiva kolegama i da li je prepoznata kao kriterijum naučno-nastavnog napredovanja. (Ćulum i Ledić, 2011:47)

\section{Zaključna razmatranja}

Nakon prikaza nekih od značajnih promena u načinu funkcionisanja današnjih univerziteta možemo da zaključimo da se usled povećane složenosti pred univerzitetima javljaju brojni izazovi. Posledice spoljašnjih uticaja na univerzitete rezultiraju i sve brojnijim 
promenama u akademskoj profesiji. Za potrebe ovog rada pažnju smo usmerili na društveni angažman akademskog osoblja u okviru proučavanja treće misije univerziteta, koji u Republici Srbiji u akademskoj zajednici još uvek nije dovoljno aktuelizovan, pa se iz tog razloga javlja velik broj pitanja i dilema.

Neka od često postavljenih pitanja u radovima koji se bave proučavanjem odnosa univerziteta i njegovog okruženja, odnosno angažovanja univerziteta u zajednici jesu: Kako akademsko osoblje konceptualizuje angažovanje zajednice i povezane koncepte u institucijama visokog obrazovanja? Koji su trenutni modeli za angažovanje zajednice na visokoškolskim ustanovama i šta podrazumeva univerzitet koji je društveno angažovan? Nacionalni saveti i komiteti zahtevaju političku, direktivnu i birokratsku odgovornost, ali šta je sa institucionalnom kulturom? Da li institucije još uvek imaju svoje nasleđene obrasce u smislu dominantnih tradicija, simbola i obrazaca ponašanja koji su ostali svojstveni usprkos širim promenama koje menjaju visokoškolsko okruženje? (Jansen 2004, prema: Bender, 2008).

Gaj Najv (Guy Neave, 2000 prema: Kwiek, 2006) prezentuje šest pitanja koja svako društvo treba da postavi u odnosu sa univerzitetom: Kako je zamišljena zajednica kojoj je univerzitet odgovoran? Koja je uloga vlade u kontrolisanju ili upravljanju univerzitetom? Koje je mesto akademske zajednice u zemlji? Da li je univerzitet institucija za stabilnost ili promene? Koju ulogu ima preneto i generisano znanje od strane univerziteta prema društvenom razvoju? Treba li društvo kroz vladu da odredi tip znanja koje treba da ima prioritet na univerzitetu?

Odgovori na ova pitanja mogli bi da budu polazna osnova za dalji istraživački rad u domenu proučavanja odnosa univerziteta i njegovog okruženja, čime bi takođe jasnije bila pozicionirana i uloga univerzitetskih nastavnika u okviru njihove akademske profesije. Nesporna je činjenica da se i univerziteti, kao i akademska profesija nalaze pred brojnim izazovima i složenostima, ali i pored novih uloga i zahteva koji im se nameću, tradicionalne uloge ne smeju da budu ugrožene i zanemarene zbog trenutnih društvenih zahteva. Sa druge strane, negiranje, ili ignorisanje promena i novih zahteva koji se od univerziteta i akademske profesije očekuju, takođe bi se negativno odrazili na visokoškolsko obrazovanje, jer bez obzira na stav o (ne)potrebi intenziviranja odnosa i saradnje univerziteta i okruženja, oni su neminovnost današnjice u kojoj se univerziteti i celokupna akademska zajednica nalaze i deluju, a u budućnosti mogu da poprime još veći značaj. 


\title{
Radovan Grandić,
}

Faculty of Philosophy,

University of Novi Sad, Serbia

Bosanac Maja,

Faculty of Philosophy,

University of Novi Sad, Serbia

\section{CHANGES IN ACADEMIC PROFESSION AND SOCIAL ENGAGEMENT OF UNIVERSITY TEACHERS}

\begin{abstract}
The openness of universities towards communities has become the subject of numerous critique, but and new oportunities as well. Regardless of the approach from which proceeds, the openness of universities towards communities is indispensable part of the functioning of universities nowadays. Besides teaching and research, as a basic academic activities, the third mission of university is increasingly discussed, which in the broadest sense can be defined as the interaction between the universities and communities, which largery affects the educational policies, both, at the local and global level. The goal of the paper, is to realize the role of university teachers in the field of social engagement, which is presented through a review of research in the Republic of Serbia realized by the Center for Educational Policies. In addition, in the analytical part of the paper, attention is paid to reinterpretation of academic profession, as well as presenting various possible scenarios of the future of academic profession. Bearing in mind that this area of research has been insufficiently studied in the Republic Serbia, in conclusion, we raise questions that might be relevant to both, pedagogical theory and practice.
\end{abstract}

Keywords: university, community, role of teachers

\section{Literatura}

1. Bender, G. (2008). Exploring conceptual models for community engagement at Higher Education Institutions in South Africa: Conversation. Perspectives in Education, 26(1), 81-95.

2. Clark, B. R. (1997). Small worlds, different worlds: The uniqueness and troubles of American academic professions, Daedalus (4), 21-42. 
3. Dimić, Z. (2013). Rađanje ideje univerziteta. Sremski Karlovci, Novi Sad: Izdavačka knjižarnica Zorana Stojanovića.

4. Gibbons, M., Limoges, C., Nowotny, H., Schwartzman, S., Scott, P.,Trow, M. (1994). The New Production of Knowledge: The Dynamics of Science and Research in Contemporary Societies. London: Sage.

5. Gojkov, G., Stojanovic, A., \& Rajic, A. G. (2015). Quo Vadis Universitas? (Organizational Concepts-Imperatives For Success And Value). Interdisciplinary Management Research, 11, 558-568.

6. Gvozdenović, S. (2010), Univerzitet između potreba i mogućnosti, Sociološka luča $4(1), 53-65$.

7. Kwiek, M. (2006). The university and the state. A study into global transformations. Frankfurt and New York: Peter Lang.

8. Ledić, J., Ćulum, B. (2011). Sveučilišni nastavnici i civilna misija sveučilišta, Rijeka: Filozofski fakultet u Rijeci.

9. Lombardi, J. V., Craig, D. D., Capaldi, E. D., Gater, D. S., \& Mendonça, S. L. (2001). Quality engines: The strategic principles for competitive universities in the twentyfirst century. US: The Center for Measuring University Performance.

10. Marcelic, S. (2015) Suvremeni modeli sveučilišta i njihova kritika u društvenim znanostima. Socijalna ekologija, 24 (1), 41-62.

11. Milutinović, J. (2008). Ciljevi obrazovanja i učenja u svetlu dominantnih teorija vaspitanja 20. veka, Novi Sad: Savez pedagoških društava Vojvodine.

12. Mugabi, H. (2014). Institutionalisation of the 'third mission'of the university: The case of Makerere University. Tampere: Tampere University Press.

13. Rončević, N., Rafajac, B. (2010). Promjene u akademskoj profesiji: komparativna analiza, Rijeka: Filozofski fakultet u Rijeci.

14. Scott, P. (1997). The changing role of the university in the production of new knowledge. Tertiary education and management, 3(1), 5-14.

15. Turk, M. (2016). (Nove) kompetencije akademske profesije u Europi. Napredak: časopis za pedagogijsku teoriju i praksu, 157(1-2), 145-164.

16. Vincent-Lancrin, S. (2004). Building futures scenarios for universities and higher education: an international approach. Policy Futures in Education, 2(2), 245-263.

Interent izvori: 
17. Univerzitet i treća misija u regionu i šire: Društveni angažman akademskog osoblja u Srbiji (2013) dostupno na:

http://www.finhed.org/media/files/Dru\%C5\%A1tveni\%20anga\%C5\%BEman\%20aka demskog\%20osoblja\%20u\%20Srbiji\%20-\%20Ivana\%20Zivadinovic.pdf (pristupljeno 07.07.2018.) 